\title{
F5 Leiden Allele
}

National Cancer Institute

\section{Source}

National Cancer Institute. F5 Leiden Allele. NCI Thesaurus. Code C91334.

Human F5 Leiden allele is a variant form of the F5 gene that is located in the vicinity of $1 \mathrm{q} 23$ and is approximately $75 \mathrm{~kb}$ in length. This allele, which encodes coagulation factor $\mathrm{V}$ Leiden protein, is involved in hypercoagulability due to resistance to degradation by activated protein $\mathrm{C}$. 